\title{
The Court of Justice at the Crossroads: Clarifying the Role for Fundamental Rights in the EU Copyright Framework
}

\author{
Stijn van Deursen • Thom Snijders
}

Published online: 4 September 2018

(C) The Author(s) 2018

\begin{abstract}
In the EU, the complex relationship between copyright and fundamental rights is accommodated in inter alia the Copyright Directive, which uses an internal system of exhaustive exceptions and limitations to copyright. However, it remains unclear whether fundamental rights can serve as autonomous grounds for limiting a copyright. Recently, the German Federal Supreme Court referred preliminary questions to the CJEU in the so-called Afghanistan Papiere case in order for the CJEU to address this unclarity. To sketch the context in which these questions have to be answered, this article explores the tension between copyright and fundamental rights in the EU legal order and identifies the boundaries of the system of exhaustive exceptions and limitations. After describing the EU legislative framework, it offers a typology of the CJEU's case law, before moving onto the ECtHR's Ashby Donald judgment, in which the issue of balancing copyright and other fundamental rights was addressed. It follows that whereas the Copyright Directive and the CJEU do not seem to allow for an external role for fundamental rights, this exact role seems to be required by the ECtHR for certain types of cases. This difference is assessed in light of the relationship of the two courts, which is essentially characterised by a need to prevent divergence between them. It is argued that the pending preliminary questions can probably be answered using the internal system of the Copyright Directive, but that they clearly indicate the limitations and problems connected to the CJEU's current approach towards copyright and fundamental rights.
\end{abstract}

Keywords Copyright Directive - Exceptions and limitations · Fundamental rights · External balancing $\cdot$ ECtHR $\cdot$ CJEU

S. van Deursen · T. Snijders ( $\square)$

Utrecht University, Utrecht, The Netherlands

e-mail: t.snijders@uu.nl 


\section{Introduction and Background}

Copyright and fundamental rights such as freedom of information have a rather complex relationship. ${ }^{1}$ Whereas freedom of information seeks to ensure and protect the free flow of information and ideas, copyright can serve as the basis for claiming a monopoly on subject matter in which information and ideas are laid down, which may have an inhibiting effect on their dissemination. ${ }^{2}$ At the same time, a copyright also provides an individual with the possibility to exploit his or her work and may thereby serve as an incentive to create new works. In this way, copyright also has a stimulating effect on the availability of information and ideas. ${ }^{3}$

In the European Union, the relationship between copyright and fundamental rights is regulated by among others the Copyright Directive, which also features a system of exceptions and limitations to a copyright, and thereby incorporates the tension between the different interests involved in an internal balancing act. ${ }^{4}$ However, under this approach it remains unclear to what extent fundamental rights can still have an autonomous role, and it is argued that there are cases in which fundamental rights should outweigh the rights of a copyright holder, even though neither an exception nor a limitation is applicable. An example of this can be found in last years' preliminary questions of the German Federal Supreme Court, asking the Court of Justice of the European Union (CJEU) in essence to what extent freedom of information can, under the regime of the Copyright Directive, still serve as a direct limitation to the exclusive rights of the copyright holder, in addition to the exceptions and limitations provided for in the Directive. ${ }^{5}$

\footnotetext{
${ }^{1}$ The same applies of course to other fundamental rights, such as the freedom of the press and the freedom of expression. The findings of this article are therefore to a large extent also applicable to these rights. Moreover, it is important to note that intellectual property (inter alia copyright) also has the status of fundamental rights under Art. 17(2) Charter of Fundamental Rights of the European Union, Art. 1 first protocol to the ECHR and the case of Anheuser Busch v. Portugal App No. 73049/01 (ECtHR 11 January 2007). See also Sect. 3. However, for reasons of clarity this article uses the term "fundamental rights" to refer to the rights that are protecting freedoms, such as the freedom of speech and information and the freedom of the press. For more on the tension between copyright and other fundamental rights: Helfer (2003), p 48; Grosheide (2010), p. 5.

${ }^{2}$ However, a copyright does not protect the ideas as such, but rather the form in which they are laid down. See also Sect. 2.1.

${ }^{3}$ Geiger (2009), p. 3; Geiger and Schönherr (2014), p. 437; Gielen (2017), p. 480.

${ }^{4}$ Directive 2001/29/EG. Geiger (2009), pp. 2-3.

5 See German Federal Supreme Court, 1 June 2017, I ZR 139/15 (Afghanistan Papiere). In German: "Können die Grundrechte der Informationsfreiheit (Art. 11 Abs. 1 Satz 2 EU-Grundrechtecharta) oder der Pressefreiheit (Art. 11 Abs. 2 EU-Grundrechtecharta) Ausnahmen oder Beschränkungen des ausschließlichen Rechts der Urheber zur Vervielfältigung (Art. 2 Buchst. a der Richtlinie 2001/29/EG) und zur öffentlichen Wiedergabe einschließlich der öffentlichen Zugänglichmachung (Art. 3 Abs. 1 der Richtlinie 2001/29/EG) ihrer Werke außerhalb der in Art. 5 Abs. 2 und 3 der Richtlinie 2001/29/EG vorgesehenen Ausnahmen oder Beschränkungen rechtfertigen?" This question can be seen in light of a series of questions of the Federal Supreme Court relating to, among other things, the relationship between copyright and fundamental rights. See in this regard also German Federal Supreme Court 1 June 2017, I ZR 115/16 (Metal auf Metal III); and German Federal Supreme Court 27 July 2017, I ZR 228/15 (Reformistischer Aufbruch). The reference to the questions of the German Federal Supreme Court are in this article only intended to serve as an example of how the tension between copyright and the freedom of information might occur in practice. This article can be seen as setting
} 
This article seeks to analyse whether fundamental rights such as the freedom of information and freedom of the press can - and perhaps should - play an autonomous role by serving as an external ground for the limitation of a copyright. It does so by firstly exploring the EU's copyright framework as set out by the Copyright Directive and its application by the CJEU, on the basis of which a typology of the role of other fundamental rights in limiting a copyright is offered. The European Court of Human Rights (ECtHR) also plays an important role in the protection of fundamental rights in the Member States and has expressed itself on the tension between copyright and fundamental rights in the case of Ashby Donald $v$. France, which forms the subsequent subject of our investigation. After placing this judgment in light of the relationship between both courts, the relevance and consequences of the ECtHR's decision for the approach of the CJEU are discussed. Lastly, it is argued that the pending preliminary questions in the Afghanistan Papiere case indicate that there are inherent drawbacks to the way in which fundamental rights have been accommodated in the EU's copyright framework, as well as to the way the CJEU has tried to solve specific clashes between copyright and fundamental rights up till now; the Afghanistan Papiere case calls for the CJEU to provide clarity with regard to the role of fundamental rights in the EU copyright framework.

\section{The Copyright Framework of the European Union}

Copyright in the EU Member States is harmonised by several Directives, the most important of which is the Copyright Directive. ${ }^{6}$ This Directive forms the starting point of our investigation.

\subsection{The Protective Scope of the Directive: The Concept of Work}

Under the terminology of Arts. 2(a) and 3(1) Copyright Directive only works are protected. The concept of work, however, is not defined in the Directive but it is argued that the CJEU gave directions for the interpretation of this term in the 2009 Infopaq case. ${ }^{7}$ According to this case, copyright only protects subject matter that is "original in the sense that it is its author's own intellectual creation", 8 which

\footnotetext{
Footnote 5 continued

the framework in which the CJEU will probably answer these questions. Therefore, issues as the specific German legislation with regard to the access to public documents (see in this regard also for example Art. 9 and recital 60 of the Copyright Directive; Directive 2013/37/EU on the re-use of public sector information) are not taken into account.

${ }^{6}$ Commission (2004) Review of the EC legal framework in the field of copyright and related rights, SEC(2004)995, p. 3.

7 Case C-5/08 Infopaq International A/S v. Danske Dagblades Forening [2009]; See for example Griffiths (2014), p. 1103. This "harmonisation-by-stealth" approach of the CJEU, based on the unity and coherence of European law, has been discussed in for example Hugenholtz (2013), pp. 62-63; Griffiths (2011); Xalabarder (2016).

${ }^{8}$ Case C-5/08 Infopaq International A/S v. Danske Dagblades Forening [2009], para. 37.
} 
requires that the subject matter contains elements "which are the expression of the intellectual creation of the author of the work". ${ }^{9}$ With regard to written texts, an author can do so "through the choice, sequence and combination of [...] words [so] that the author may express his creativity in an original manner". ${ }^{10}$ The element of choice from a range of options therefore seems crucial for the qualification of subject matter as a work protected by copyright. Elements that are "differentiated only by their technical function", i.e. when a choice is determined by a certain desired technological effect, cannot be protected by a copyright. ${ }^{11}$

The fact that not the words as containers of information, but rather the specific sequence and combination in which they are expressed is protected by copyright, should be seen in light of a possible tension between copyright and freedom of speech: copyright does not prohibit the dissemination of the ideas that are contained in a text, but only the specific choices with regard to the sequence of the words that are used to express them. The ideas as such remain free. ${ }^{12}$

In case an object qualifies as a work, the Copyright Directive requires EU Member States to provide the author of this work with an exclusive reproduction right (Art. 2 Copyright Directive), the rights of communication to the public and right of making available to the public (Art. 3 Copyright Directive), and a distribution right (Art. 4 Copyright Directive). However, the fact that the aforementioned rights are exclusive does not mean that they are unlimited: the use of a protected work remains possible on the basis of authorisation by the copyright holder or because of the applicability of one of the exceptions or limitations that are listed in the Copyright Directive.

\subsection{An Exhaustive List of Exceptions}

Article 5 Copyright Directive provides for one mandatory and 20 optional exceptions and limitations, which can be invoked to justify the use of a protected work and thereby fulfil an important function in reaching a balance between copyright and rights and interests of others. ${ }^{13}$ They provide, under strict conditions,

\footnotetext{
9 Ibid., para. 39.

${ }^{10}$ Ibid., para. 45.

11 Case C-393/09 Bezpečnostní softwarová asociace - Svaz softwarové ochrany (BSA) v. Ministry of Culture of the Czech Republic [2011]. See also in a similar vein: Cases C-403/08 and C-429/08 Football Association Premier League v. QC Leisure [2012]; Griffiths (2014), p. 1104.

12 For more on the idea/expression dichotomy, see for example: Jütte (2016), pp. 11-21.

13 Although it is argued that there is a dogmatic difference between the terms exceptions and limitations, they are used interchangeably in the context of this article. See on the differences for example Geiger and Schönherr (2014), p. 438. See further with regard to the role of exceptions and limitations in reaching a balance between copyright and fundamental rights also recital 31, stating that the Directive aims to safeguard a fair balance between both the different categories of rightholders as well as between the rightholders and the users. In the same vein Dreier (2010), p. 1; Commission (2008) Copyright in the Knowledge Economy (Green Paper) COM(2008) 466 final; Renda et al. (2015), p 13. See also for example Case C-145/10 Eva-Maria Painer v. Standard VerlagsGmbH [2012], para. 134, in which the CJEU elaborates on the role of Art. 5(3)(d) Copyright Directive, which is "intended to strike a fair balance between the right to freedom of expression of users of a work or other protected subject-matter and the reproduction right conferred on authors".
} 
for example for exceptions to the rights to reproduction and communication to the public for scientific purposes (reflecting the freedom of arts and sciences), for use by the press (reflecting freedom of the press), for quotation (reflecting freedom of information) and for use during religious celebrations (reflecting freedom of thought, conscience and religion). ${ }^{14}$

In the interpretation of the Copyright Directive, its recitals play an important role. ${ }^{15}$ For example, in line with recital 9, the CJEU's starting point in interpreting the Directive is mostly the protection of rightholders. ${ }^{16}$ This approach is in line with the Commission's Green Paper on Copyright in the Knowledge Economy, stating that the basic principle underlying the Copyright Directive is to provide the rightholders with a high level of protection. ${ }^{17}$ Moreover, according to recital 4 , one of the aims of the Directive is to increase legal certainty by providing a harmonised legal framework and thereby to promote investments in creativity and innovation, in order to stimulate competitiveness of European industry. To do so, the Copyright Directive applies a rights-owner focused approach, while - according to recital 3 - stimulating "compliance with the fundamental principles of law and especially of property, including intellectual property, and freedom of expression and the public interest".

Under this approach, the system of limitations to a copyright, being a derogation from the general principle of copyright protection, is interpreted in a rather narrow way. ${ }^{18}$ According to recital 32 , the list of limitations mentioned in the Directive is exhaustive - meaning that only the limitations contained in the Directive can be used to justify copyright infringement. In conclusion, although the possibility of providing a more open-ended character to the system of limitations was discussed during the drafting process of the Directive, ${ }^{19}$ the EU copyright acquis in its current form has a rather "right-owner"-centred perspective. ${ }^{20}$ As a result, under this interpretation of the system of limitations there seems to be no leeway for Member States to take interests into account that cannot be brought under one of the recognised limitations. ${ }^{21}$

\footnotetext{
14 In the current case, however, it would be likely for the Westdeutschen Allgemeinen Zeitung to invoke the right of use by the press or the right to quotation. However, the right of use by the press is only applicable with regard to published articles and the right to quotation only with regard to work or other subject-matter which has already been lawfully made available to the public. These conditions have not been met in the current case.

15 See for the role of recitals in interpreting legislation also the Joint Practical Guide of the European Parliament, the Council and the Commission for persons involved in the drafting of European Union legislation. http://eur-lex.europa.eu/content/techleg/EN-legislative-drafting-guide.pdf p. 31, accessed on 20 May 2018; Klimas and Vaiciukaite (2008), p. 26.

16 Case C-5/08 Infopaq International A/S v. Danske Dagblades Forening [2009] para. 40 and 59; Case C-145/10 Eva Maria Painer [2011], para. 107; Case C-138/16 AKM v. Zürs.net [2017] para. 42.

17 Commission (2008) Copyright in the Knowledge Economy (Green Paper) COM(2008) 466 final, pp. 4-5.

18 See for examples of application in case law of the CJEU: Case C-476/01 Kapper [2004], para. 72; Case C-36/05 Commission v. Spain [2006], para. 31; Case C-5/08 Infopaq International A/S v. Danske Dagblades Forening [2009], paras. 56-57; Case C-145/10 Eva Maria Painer [2011], para. 109.

19 Especially the Scandinavian countries and the Netherlands advocated the introduction of a fair-uselike clause (Renda et al. 2015, p. 28).

${ }^{20}$ Dreier (2010).

21 Mazziotti (2013), p. 73; Renda et al. (2015), pp. 27-28 and 76.
} 
A narrow interpretation of limitations also seems to be implied by the so-called three-step test of Art. 5(5) Copyright Directive. Under this test - which is argued to deviate from its models in, e.g. Art. 9(2) Berne Convention, Art. 13 TRIPS Agreement and Art. 10 WIPO Copyright Treaty - the discretion of Member States to apply the limitations that are mentioned in the Copyright Directive is not unlimited, but subject to the conditions following from Art. 5(5) Copyright Directive. ${ }^{22}$ As a result, exceptions can only apply in special cases that "do not conflict with a normal exploitation of the work [...] and do not unreasonably prejudice the legitimate interests of the right holder". It follows from the CJEU's judgment in the ACI Adam case that there is no provision in the Directive that "envisages the possibility of the scope of such exceptions or limitations being extended by the Member States". 23

The Directive does, however, leave some room for the Member States to take their own traditions into account and thereby "removes some of the rigidness inherent to a closed list of limitations". ${ }^{24}$ For example, under Art. 5(3)(o), the Directive allows for certain exceptions and limitations that already exist under national law in cases of minor importance that only concern analogue use and do not interfere with the objectives of the EU. Moreover, recital 31 makes explicit that the Directive, and its system of limitations, aim at "a fair balance of rights and interests between the different categories of rightholders" and that the degree of harmonisation of the limitations should depend on their impact on the smooth functioning of the internal market. In our view, this entails that the limitations that are allowed under the Directive are to be construed in accordance with this objective. In light of the foregoing it does, however, not mean that those rights and interests can serve as an additional limitation ground. $^{25}$

Consequently, the Copyright Directive creates a system in which the exclusive rights appear to be the rule, whereas an exhaustive list of limitations can provide for occasional exceptions. ${ }^{26}$

\subsection{Copyright and Fundamental Rights in the CJEU's Case Law}

In its case law, the CJEU has applied the system of limitations in order to reach a fair balance between copyright and other rights and interests, just as is required by the aforementioned recital 31 . However, by doing so the CJEU has always remained within the boundaries of the closed system of limitations by using fundamental rights and interests only to assess specific copyright enforcement measures and to interpret the existing limitations.

\footnotetext{
22 Geiger and Schönherr (2014), p. 442.

23 Case C-435/12 ACI Adam [2014], para. 27.

24 Van Eechoud et al. (2009), p. 103. See also Walter (2001), p. 1065.

25 See also Case C-145/10 Eva Maria Painer [2011], paras. 132-137; Renda et al. (2015).

26 Dreier (2010), p. 51.
} 


\subsubsection{Copyright Enforcement Measures}

In the 2008 Promusicae case, ${ }^{27}$ the CJEU ruled that, when transposing and interpreting the Copyright Directive, the E-Commerce Directive, ${ }^{28}$ the IPenforcement Directive ${ }^{29}$ and the ePrivacy Directive ${ }^{30}$ "the Member States take care to rely on an interpretation of them which allows a fair balance to be struck between the various fundamental rights protected by the Community legal order". ${ }^{31}$ Moreover, Member States have to "make sure that they do not rely on an interpretation of them which would be in conflict with those fundamental rights or with the other general principles of Community law, such as the principle of proportionality." 32 This case was, however, about an obligation of the Internet service provider Telefónica to communicate personal data to Promusicae in order to ensure the effective protection of the copyright. Therefore, it focused on a specific measure to enforce the copyright aimed at an intermediary. It neither related to exclusive rights of the author - i.e. the core of the copyright - nor to the possibility to limit these exclusive rights and was not aimed directly at the infringing party.

The same holds true for the 2011 case of Scarlet $v . S A B A M .^{33}$ In this case, Scarlet - an Internet service provider - invoked the fundamental right to protection of personal data in order to prevent having to provide the personal data of copyrightinfringing customers to the collective management organisation SABAM. In answer to the following preliminary questions, the CJEU argued in line with the common approach towards conflicts of fundamental rights by stating that the "fundamental right to property, which includes the rights linked to intellectual property, must be balanced against the protection of other fundamental rights". ${ }^{34}$ In order to do so "national authorities and courts must strike a fair balance between the protection of copyright and the protection of the fundamental rights of individuals who are affected by such measures". 35 It follows from these paragraphs that the CJEU again only focused on the measures protecting a copyright, i.e. an obligation for intermediaries to provide the personal data of their potentially copyright-infringing customers. Subsequently, it balanced those measures against the affected individuals' fundamental rights - i.e. the freedom to conduct business, the right to protection of personal data and the freedom to receive or impart information. ${ }^{36}$ By

\footnotetext{
27 Case C-275/06 Promusicae [2008]. See for a detailed account of this case also Groussot (2008), pp. 1745-1766; Kosta (2015), pp. 108-112.

28 Directive 2000/31/EC.

${ }^{29}$ Directive 2004/48/EC.

30 Directive 2002/58/EC.

31 Case C-275/06 Promusicae [2008], para. 70.

32 Ibid.

33 Case C-70/10 Scarlet/SABAM [2011].

34 Ibid., para. 44.

35 Ibid., para. 45.

36 See also Visser (2012), p. 1041.
} 
this approach, the core of the copyright, being the exclusive rights of the copyright holders, again remains untouched. ${ }^{37}$

\subsubsection{Interpretation of Limitations and Exceptions}

In the Premier League case, the CJEU considered the exception for temporary reproductions. ${ }^{38}$ Here we do see that the Court appears willing to interpret this exception with greater flexibility in order to ensure effectiveness of the exception and its purpose. By this approach, the CJEU seems to be moving towards the core of the copyright, i.e. the exclusive rights of the rightholders. The Premier League case focused on the question whether an act of reproduction can benefit from the exception for temporary acts of reproduction, as provided for in Art. 5(1) Copyright Directive, while not being able to fulfil all of its conditions. The CJEU argued that "the interpretation of those conditions must enable the effectiveness of the exception thereby established to be safeguarded and permit observance of the exception's purpose as resulting in particular from recital 31 " ${ }^{39}$ It continued by stating that

"in accordance with its objective, that exception must allow and ensure the development and operation of new technologies and safeguard a fair balance between the rights and interests of right holders, on the one hand, and of users of protected works who wish to avail themselves of those new technologies on the other." 40

On the basis of this line of reasoning, the Court concluded that, although formally not fulfilling all of its requirements, Art. 5(1) Copyright Directive could still be relied upon. In the following case of Eva Maria Painer, ${ }^{41}$ the CJEU followed this line by stating that the conditions for invoking Art. 5(3)(d) Copyright Directive (quotation exception) have to be interpreted strictly (see in this regard also Sect. 2.2), while at the same time enabling the effectiveness of the exception and observing its purpose. ${ }^{42}$ In the case of Deckmyn $v$. Vandersteen ${ }^{43}$ the CJEU pointed out that the same applies for the parody exception of Art. 5(3)(k) Copyright Directive, which has be interpreted against the background and purpose of the

\footnotetext{
37 A similar approach is applied in Case C-360/10 SABAM v. Netlog [2012], on the role of the fundamental right of freedom to conduct business, the right to protection of personal data and the freedom to receive or impart information in relation to a system for filtering that information in order to prevent files being made available which infringe copyright. See also Case C-314/12 UPC Telekabel Wien [2014], on the freedom to conduct a business in relation to an order addressed to an internet service provider prohibiting it from giving its customers access to a copyright-infringing website; Case C-484/14 McFadden v. Sony Music [2016] in which a filtering obligation is balanced against the freedom to conduct a business and the freedom of information.

38 Case C-403/08 and 429/08 Football Association Premier League [2011].

39 Ibid. para. 163.

40 Ibid. para. 164.

41 Case C-145/10 Eva Maria Painer [2011].

42 Ibid., paras. 132-137.

43 Case C-201/13 Deckmyn v. Vandersteen [2014].
} 
limitation system, i.e. to strike a fair balance between the rights and interests involved. $^{44}$

\subsection{Typology of the Role of Fundamental Rights Under the Copyright Directive}

In our view, taking the foregoing into account, it is important to distinguish between three stages on which other fundamental rights can play a limiting role under the EU's copyright framework. The first stage focuses on the exclusive rights of the copyright holder, and therefore on the core of the copyright. The second stage relates to the exceptions and limitations to these rights. The third stage centres around measures to ensure their enforcement.

On the first stage, the limiting role of rights and interests of others is most important during the law-making process and in establishing whether specific subject matter qualifies as a work that is protected by copyright. By not protecting information and ideas as such - but rather the specific form in which they are expressed - and by allowing for limitations and exceptions to a copyright the position of the freedom of information is to a large extent protected. Up to now, the CJEU has not expressed itself on the limiting role of other fundamental rights in cases in which certain subject matter does qualify as a work and is therefore protected by copyright, whereas no exceptions or limitations are applicable. In the following it is argued that it follows from the current line of case law that the limiting role of other fundamental rights is restricted to specific enforcement measures aimed at intermediaries and the interpretation of the existing limitations and exceptions and that they cannot fulfil an external balancing role.

In its case law, the CJEU has always focused on the role of other fundamental rights in the second and third stage. In the second stage it has remained within the boundaries of the existing limitations and exceptions. According to the line of case law on this type of case, limitations to copyright are to be considered derogations from the general rule of protection of the exclusive rights of the copyright holder. Therefore, in principle, they have to be interpreted strictly. However, their purpose is at the same time to ensure a fair balance of the different rights and interests that are involved, and the exceptions and limitations have to be interpreted against this background. By doing so, the CJEU has extended the scope of the limitations by interpreting their conditions in a more lenient way, especially in cases in which emerging technologies require so. The CJEU has, however, never acknowledged the possibility to invoke a fundamental right as an autonomous ground for the justification of a prima facie copyright infringement.

Fundamental rights play the most important role on the third stage according to the case law of the CJEU. Here, specific copyright measures have to be balanced

\footnotetext{
44 Ibid., paras. 21-24. Other fundamental rights can have a similar role in the interpretation of the exclusive rights of the copyright holder, but - because of the focus of this article on the role of fundamental rights in limiting a copyright - this is not further discussed at this point. It is, however, interesting to note that the interpretation of exclusive rights and the limitations to this right are to certain extent communicating vessels: a broader interpretation of the exclusive rights will lead to a more narrow interpretation of the limitations to these rights. See in this regard also Case C-403/08 and C-429/08 Football Association Premier League [2011]; Case C-607/11 ITV Broadcasting [2013].
} 
against potentially conflicting fundamental rights. Fundamental rights can in this way therefore serve as an autonomous ground for the limitation of specific copyright enforcement measures. By this approach, the copyright itself remains intact, but a particular way of enforcing it is excluded. It is important to note that the case law on this topic of the CJEU relates to intermediaries (such as internet service providers) and not to the infringing parties as such.

\section{The Approach of the ECtHR: Ashby Donald and Others v. France}

In 2013, the ECtHR delivered a judgement in the case of Ashby Donald and others $v$. France, in which it made a number of observations pertaining to the nature of the fundamental rights tension in copyright enforcement, as well as the extent to which national courts enjoy a margin of appreciation in balancing fundamental rights. Even though the CJEU has also ruled multiple times in cases concerning the enforcement of copyright, such as in UPC Telekabel, it has - as mentioned in Sect. 2.4 - always restricted itself to reviewing the legitimacy of specific forms of enforcement. It has not - as of yet - set out a general framework of how conflicting fundamental rights in copyright enforcement should be balanced by national courts, which is exactly what the ECtHR does in Ashby Donald. ${ }^{45}$

In the case of Ashby Donald, three photographers had taken photographs of couture at Paris fashion shows and had published these fashion photographs via a website without the permission of the labels. The fashion houses then claimed infringement of their copyright under French law. At the French court of first instance, their claim was denied, but on appeal, the photographers lost. Consequently, they received fines and had to pay damages to the fashion houses and the French design clothing federation. Taking the case up to the French Supreme Court, the photographers then relied on an exception provided for in French copyright law, and also on Art. 10 European Convention on Human Rights (ECHR), providing for freedom of expression. After the French Supreme Court rejected this appeal, the photographers took the case to the ECtHR in Strasbourg, claiming their right to freedom of expression had been violated by the French court. $^{46}$

The first important aspect of the subsequent ECtHR ruling is the approach the ECtHR takes in its general conceptualisation of the clash of the two conflicting interests. The Court recognises that both parties' interests represent fundamental rights contained in the Convention and the protocols. The rights of freedom of expression and information are contained in Art. 10 ECHR, whereas the right to property - which has been recognised to include intellectual property - is protected in Art. 1 of the first protocol to the ECHR. ${ }^{47}$ Having identified these conflicting rights, the ECtHR holds that the conviction for the breach of copyright and the award of damages have to be regarded as interferences with the right of freedom of

\footnotetext{
45 Ashby Donald v. France App No. 36769/08 (ECtHR, 10 January 2013).

46 Ashby Donald v. France App No. 36769/08 Legal Summary (ECtHR, 10 January 2013).

47 Anheuser Busch v. Portugal App No. 73049/01 (ECtHR 11 January 2007), para. 72.
} 
expression and information. ${ }^{48}$ The ECtHR thus views a copyright enforcement claim as an invocation of an exception to the rights of freedom of expression and information. Those rights, in the eyes of the ECtHR, are therefore to be seen as the default point of departure for these kinds of disputes. ${ }^{49}$ This approach towards copyright is certainly different from the basic premise underlying the Copyright Directive, which is principally oriented towards copyright holders. ${ }^{50}$ It also differs from the approach taken by the CJEU, which entails that derogations to the general principle of copyright should be interpreted strictly, and can at most constitute a limitation or exception to the general principle. ${ }^{51}$

Secondly, after it identifies a conflict between these two fundamental rights, the ECtHR holds that the finding of an interference with Art. 10 ECHR inevitably requires a balancing test. ${ }^{52}$ In its further substantiation of the requirements of such a test, the ECtHR clarifies that national courts have a certain margin of appreciation in striking a balance between conflicting rights. In line with its previous case law, the ECtHR distinguishes between cases concerning "commercial speech" on the one hand and cases concerning speech in a "general public interest" on the other, as the type of speech is of particular importance to the scope of the margin of appreciation of national courts. ${ }^{53}$ It holds that in cases in which the exercise of the right to freedom of expression entails a kind of commercial speech, national courts are provided with a particularly wide margin of appreciation in dealing with interferences of that right. When monetary gain is the primary incentive for publishing copyrighted material a case will most likely fall under the header of commercial speech. Accordingly, in Ashby Donald, the Court found that the publishing of the photographs had been profit-motivated, and therefore the French court was given a wide margin of appreciation in deciding whether a proper balance had been struck. ${ }^{54}$ Consequently, the ECtHR only conducted a marginal review of the balancing test carried out by the French court of appeals and deemed that there was no violation of Art. 10.

However, this could have been different if the case concerned what the ECtHR has termed a "general public interest", as in such cases the margin of appreciation for national courts is reduced. It follows from the case of Mouvement Raëlien Suisse v. Switzerland that there is little scope under Art. 10(2) ECHR for restrictions on political speech or on debate of questions of public interest. ${ }^{55}$ In Ashby Donald, the Court also articulates types of potential cases which may deserve to be labelled as concerning a general public interest. These may include, for example, cases involving "use of public documents" or "journalists and media exercising their

\footnotetext{
48 Torremans (2014), p. 97; Voorhoof and Høedt-Rasmussen (2013), p. 2.

49 Geiger and Izyumenko (2014), p. 324.

50 See also Sect. 2.2.

51 Izyumenko (2016), p. 116.

52 Voorhoof and Høedt-Rasmussen (2013), p. 8.

53 The importance of this distinction had been stressed earlier by the Court in Mouvement Raëlien Suisse v. Switzerland, para. 61.

54 Voorhoof and Høedt-Rasmussen (2013), pp. 2-3.

55 Mouvement Raëlien Suisse v. Switzerland App No. 16354/06 (ECtHR, 13 July 2012).
} 
public watchdog function in a democracy". 56 In such cases, a national court would only have a small margin of appreciation and should carefully balance the conflicting fundamental rights. Still, the question whether a specific exercise of the right to freedom of expression should be categorised as involving a general public interest or as a form of commercial speech, is to be decided on a case-by-case basis. ${ }^{57}$

Since the case of Ashby Donald concerned "commercial speech" and the national court thus had a wide margin of appreciation, the ECtHR did not articulate the precise standards that such a careful balancing act needs to meet. ${ }^{58}$ Nevertheless the case of Ashby Donald makes way for a "second layer" of balancing fundamental rights beyond the currently existing system of an exhaustive list of legitimate limitations and exceptions. ${ }^{59}$ This external balancing act would entail a case-bycase assessment of the legality and proportionality of a copyright enforcement measure, as well as its necessity in a democratic society. ${ }^{60}$ Even though the Copyright Directive's current system of an exhaustive list of possible limitations and exceptions already incorporates the tension between the rights to freedom of expression and information and the right to property to a certain extent, this cannot be understood as precluding an external balancing act in the eyes of the ECtHR. Thus, while both courts seem to agree that a fair balance should be struck between conflicting fundamental rights, the ECtHR adds an external balancing of fundamental rights whereas the CJEU has as of yet not left the internal system of exhaustive limitations and exceptions.

\section{The Dynamic Relationship Between the CJEU and the ECtHR}

As secondary EU law, the Copyright Directive falls under the overarching structure of the EU fundamental rights framework. Evident, however, is that the EU is not the sole guardian and provider of fundamental rights on the European level: the ECHR and the ECtHR also set fundamental rights standards to which all Council of Europe Member States - these include all EU Member States - should adhere. The ECHR and ECtHR have played, and continue to play, an important role in shaping fundamental rights protection by the EU. Hence, the relevance of the Ashby Donald case before the ECtHR for the EU copyright framework is better understood when taking account of some of the driving forces that characterise the relationship between the CJEU and ECtHR.

Historically, fundamental rights were firstly recognised as sources of EU law by way of their status as general principles; Art. 6(3) TEU states that fundamental rights, as guaranteed by the ECHR and the constitutional traditions of the Member States, shall constitute General Principles. Later on, with the adoption of the Lisbon

\footnotetext{
56 Voorhoof and Høedt-Rasmussen (2013), p. 7; Mouvement Raëlien Suisse v. Switzerland App No. 16354/06 (ECtHR, 13 July 2012).

57 De Cock Buning (2014), p. 243.

58 Jütte (2016), p. 16.

59 See De Cock Buning (2014), pp. 244-245; Jütte (2016), p. 16.

60 De Cock Buning (2014), pp. 244-245.
} 
Treaty in 2009, the status of fundamental rights in EU law was consolidated further, both through the Charter of Fundamental Rights (hereinafter: CFR or Charter) becoming legally binding, as well as the EU's ambition to accede to the ECHR. ${ }^{61}$ In both instances, the ECHR and ECtHR's case law served as a key source for guidance and inspiration. ${ }^{62}$ Moreover, both the aim of accession as well as the adoption of the Charter have led to an increased significance of fundamental rights in the case law of the CJEU in general. ${ }^{63}$

Article 52(3) CFR states that the meaning and scope of the rights included in the CFR should be the same as the corresponding rights in the ECHR. ${ }^{64}$ The Explanations to this provision then add that their meaning and scope is not only found by looking at those corresponding rights, but also by taking into account the case law of the ECtHR. ${ }^{65}$ The same paragraph also provides that the EU can offer a higher level of protection. In addition, Art. 53 CFR states that the Charter cannot restrict or adversely affect the level of protection of fundamental rights already provided by Union law, international law (in particular the ECHR), and the Member States' constitutions and thereby creates a minimum level of protection which is determined in part by the ECHR and the ECtHR.

Yet, with regard to the ECtHR it has been questioned to what extent the CJEU is under an actual obligation to take its case law into account, as the Explanations are not legally binding. ${ }^{66}$ Juliane Kokott, Advocate General to the CJEU, has explained that the case law of the ECtHR has persuasive authority when it comes to determining the nature of the shared constitutional traditions of the Member States in the context of General Principles, but it cannot be considered formally binding. ${ }^{67}$ However, she also refers to then CJEU president Vasilios Skouris, who has pinpointed that although there is no binding authority of Strasbourg case law in a strict theoretical sense, it possesses a de facto authoritative status. ${ }^{68}$

Moreover, in a considerable number of cases, the CJEU - in its application of CFR rights - has referred to the interpretations of the ECtHR of corresponding ECHR rights. ${ }^{69}$ Recently, a decrease in the frequency with which the CJEU refers to Strasbourg case law in the post-Lisbon era has been noticed; this can be attributed in part to the rise of references to the Charter and the CJEU's own case law, but, according to empirical research, is also caused by increasing work-loads and limited time. $^{70}$ Nevertheless, the influence of the Strasbourg court on the CJEU extends

\footnotetext{
61 Douglas-Scott (2011), p. 646; De Búrca (2013), p. 169.

62 Harpaz (2009), p. 108.

63 Hartkamp (2016).

64 Jans et al. (2015), p. 155.

65 Explanations Relating to the Charter of Fundamental Rights, C 303/33; see also Jans et al. (2015), p. 155 .

66 Krommendijk (2015), p. 815

67 Kokott and Sobotta (2015), p. 63.

68 Kokott and Sobotta (2015), p. 64.

69 Mjoll Arnardottir and Buyse (2016), p. 30; Jans et al. (2015), p. 156.

${ }^{70}$ Krommendijk (2015), p. 823.
} 
beyond mere references in judgments, for instance through the argumentation

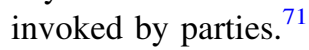

This de facto importance of the case law of the ECtHR for the CJEU is underlined by two connected factors. First, the emergence of fundamental rights in the EU leads to the parallel existence of two regional fundamental rights regimes, meaning that individuals in EU Member States fall under the protection of two different binding texts at the same time - and that these are applied and interpreted independently by two different courts. $^{72}$ Consequently, profoundly differing interpretations of fundamental rights by those courts could lead to inconsistent practices and an incoherent system of fundamental rights protection in Europe, and eventually result in legal uncertainty. In order to avert the risks connected to divergent and contradictory practices between the application of fundamental rights by the two courts, different legal mechanisms such as Art. 52(3) CFR have been devised, but also informal mechanisms were set up, such as working meetings with judges of both courts and inter-institutional information exchange. ${ }^{73}$

Second, on the part of the CJEU, the need for convergence with the Strasbourg regime is underlined by the EU's commitment to accede to the ECHR, as this means that eventually all EU institutions, including the CJEU, will be formally bound by the Convention and the case law of the ECtHR. This objective has been codified in Art. 6(2) TEU which was adopted together with the Charter. Even though the CJEU in 2014 issued a negative opinion on the proposed accession agreement - which will effectively postpone accession for an indefinite amount of time - it is unlikely that this will lower the status of the ECtHR's case law for the CJEU. ${ }^{74}$

It should be clear that the CJEU decides its cases on the basis of the CFR and EU law, and the ECtHR on the basis of the ECHR. Turning back to the Ashby Donald judgment, this may clarify the difference between the conceptualisation of the ECtHR, which takes copyright as the exception to freedom of expression, and the CJEU, which departs from the exclusivity of copyright. It could also explain why the ECtHR is more apt to resort to an "external" balancing act to address the conflict between copyright and the freedom of expression in certain types of cases than the CJEU, which looks first at the internal system in which a politically struck balance between fundamental rights has already been articulated.

Clearly, each court resorts to its own catalogue of fundamental rights, and the counterpart has no direct legal status for that court. ${ }^{75}$ This also means that the CJEU is not strictly bound by the ECHR or the judgments of the Strasbourg court as such, but primarily through their use in identifying General Principles or when interpreting Charter rights. However, the need to maintain convergence implies an informal obligation on the part of the CJEU to ensure that its decisions do not deviate too much from those of the ECtHR. In that sense, it constrains the CJEU to a

\footnotetext{
71 Harpaz (2009), p. 109.

72 Similarly, this means that EU Member States, when having to implement EU law, are at the same time bound by their ECHR obligations for which they can be held accountable. See also Harpaz (2009), p. 119.

73 Jans et al. (2015), p. 156.

74 Kokott and Sobotta (2015), p. 73.

75 Jans et al. (2015), p. 155.
} 
certain extent when making decisions in cases involving fundamental rights. Despite their lack of direct legal status, the ECtHR's judgments do help shape the position taken by the Court of Justice in cases that are alike. The CJEU has referred to Strasbourg judgments in many cases, and this exemplifies their persuasive status in cases in which fundamental rights need to be balanced. ${ }^{76}$ Albeit true that the value of the ECtHR's case law remains formally dependent on the view taken of it by the CJEU, the EU fundamental rights framework effectively does not stand in absolute isolation from the Strasbourg regime. ${ }^{77}$

The question is then how the ECtHR's ruling is to be understood in light of the aim of convergence between the two fundamental rights regimes and what normative weight ought to be accorded to the findings of the ECtHR in future cases before the CJEU. As became clear in the previous section, the aim of convergence ascribes de facto authoritative status to the ECtHR's judgments. Surely, there are no formally binding obligations on the part of the CJEU to mitigate the observations made by the ECtHR in Ashby Donald in its future case law. Yet, the nature of the relationship between the two courts, which is characterised by a need to protect the coherence of the two fundamental rights regimes and constrained further by the EU's aim of accession, seems to beg for a tactful approach by the CJEU in future cases.

\section{The Afghanistan Papiere Case: The Current EU Approach Put to the Test}

In 2012, the German newspaper Westdeutschen Allgemeinen Zeitung (hereinafter: WAZ) applied for an inspection of the secret governmental reports on the German military mission in Afghanistan, but this application was rejected on grounds of national security. However, the WAZ managed to acquire access to said secret reports and published them on its online portal, referring to them as the "Afghanistan Papiere". In order to stop this unauthorised use of the documents by the WAZ, the German State applied for an injunction on the basis of, inter alia, the infringement of its copyright. The WAZ could not rely on the exception for reproduction by the press and the quotation exception, as both provisions require that the documents have been made available to the public, which was not the case, as the documents concerned were secret. ${ }^{78}$ Therefore, the WAZ invokes the freedom of information and the freedom of the press as autonomous grounds that should override the rights of the copyright holder. In light of the foregoing analysis of the approaches of both the CJEU and the ECtHR, it is not surprising that the German Federal Supreme Court referred preliminary questions to the CJEU to essentially find out whether the fundamental rights of freedom of information and freedom of the press can still be invoked by way of an external balancing act.

\footnotetext{
76 Morana-Foadi and Andreadakis (2011), p. 1072.

77 Kokott and Sobotta (2015), p. 65.

78 Art. 5(3) sub. c Copyright Directive, stating that this exception is only applicable to the "making available of published articles" and Art. 5(3) sub. d Copyright Directive, providing that the quotation exception only applies to "work or other subject-matter which has already been lawfully made available to the public".
} 
The CJEU has not yet answered the questions, but in light of the foregoing analysis in this article, it is hoped that the answers will provide clarity on the exact role of fundamental rights in the EU copyright framework and will reflect the approach of the ECtHR. In this respect, it is relevant to reiterate the distinction made by the ECtHR between cases primarily concerning commercial speech and those concerning a general public interest. In the first category of cases, national courts have a wide margin of appreciation in striking an external balance between fundamental rights, so that in most cases they will not be scrutinised closely by the ECtHR. However, in the latter category, this margin of appreciation is reduced, and the ECtHR will examine closely whether a proper balance has been struck. In this sense, Afghanistan Papiere might be illustrative of the type of case the ECtHR envisioned, as it clearly resonates with the examples given by the court of a case concerning a general public interest: the Court explained that cases concerning the "use of public documents" or "journalists and media exercising their public watchdog function in a democracy", are likely to qualify as concerning a general public interest. Clearly, the Afghanistan Papiere case involves journalists revealing sensitive public documents in the name of providing transparency. In other words, the ECtHR would probably pay close attention to the balancing act conducted by the national court. Potentially, this would also be a case in which the ECtHR would deem an external balancing to be necessary in order to strike an adequate balance. The CJEU, however, has adhered to the internal balance within the Copyright Directive, which was struck by the EU legislator. In the following concluding Section, the Afghanistan Papiere case is placed in light of both approaches.

\section{Conclusion}

This article has explored the relationship between copyright and other fundamental rights under the EU Copyright Directive, and in particular whether these other fundamental rights can be used to limit a copyright - next to the system of exceptions of limitations of the Copyright Directive. It follows from the foregoing that the Copyright Directive aims to create a high level of protection for copyright holders and therefore applies an exhaustive system of exceptions and limitations, implying that only the exceptions and limitations that are mentioned in this Directive can be used in order to limit a copyright. Furthermore, in the view of the CJEU, limitations and exceptions are derogations from the principle of a high level of protection and these should therefore be interpreted strictly. By this approach, the CJEU adheres to the exhaustive system and it thereby leaves the Copyright Directive intact. At the same time, on the basis of the recitals of the Directive, the Court often stresses that any interpretation of the limitations and exceptions has to safeguard the effectiveness of the exception, meaning that a fair balance between copyright and rights and interests of third parties should be reached. In order to attain these objectives, the Court has cautiously expanded the role of fundamental rights in the internal system of limitations. According to the CJEU, fundamental rights can serve as an interpretative standard for the existing exceptions and as an assessment standard for specific enforcement measure aimed at intermediary parties. 
So far, however, fundamental rights have not been used by the CJEU as an autonomous ground for the limitation of the exclusive rights of a copyright holder.

The ECtHR applies a different approach, as it ruled that copyright enforcement measures in general should be adequately balanced with other fundamental rights and thereby added a new, external layer to the copyright framework. Differing from the CJEU's approach, this does not mean that only specific copyright enforcement measures aimed at intermediaries can be excluded, but rather that in particular cases, enforcement measures in general can be excluded. As this results in a situation in which copyright holders are not able to enjoy their copyrights and the relating right to enforcement to their full extent, this could be seen as a de facto limitation of their copyright.

The CJEU is not formally bound to follow the reasoning of the ECtHR underpinning the Ashby Donald ruling. However, the importance of convergence between the two courts implies that the CJEU takes into account the normative significance of the ECtHR's Ashby Donald judgment and that it will have to accommodate this in its future judgments, in spite of its contrasting approach.

The preliminary questions of the German Federal Supreme Court in the Afghanistan Papiere case exemplify the sensitivity of the issue, as these clearly show the tension between copyright and other fundamental rights - and the potential inadequacy of the internal system to deal with this tension - to its full extent. According to the ECtHR's approach, this case would most likely require an external balancing of the government's interest of copyright enforcement on the one hand and the interests of freedom of information and of the press of the newspaper and the general public on the other. However, the CJEU has to date not allowed for such an external balancing act and it therefore seems likely that it will try to accommodate the case in its internal approach. In that case it will have to depart from the strict requirement that copyright protected material has to be made available to the public for invoking one of the exceptions and limitations of the Copyright Directive. Although examples of a broad interpretation of exceptions and limitations can already be found in the CJEU's case law, departing from of one of the strict requirements for invoking one of the exceptions is to be considered a next step.

The questions of the German Federal Supreme Court in the Afghanistan Papiere case serve as another example of the inherent boundaries of the way in which fundamental rights are incorporated in the Copyright Directive. Nevertheless, this specific case will not necessarily force the CJEU to open up the closed system of limitations of the Copyright Directive. Taking into account the CJEU's case law, the Court has shown itself committed to the Copyright Directive's internal system of possible exceptions and limitations, and a sudden shift from that closed system to a system that provides for an external balancing of copyright with fundamental rights therefore seems unlikely. However, if the CJEU does not want to diverge altogether from the ECtHR's approach - which does require external balancing in certain cases - it looks like it will at least have to refrain from a strict interpretation of the Directive. Rather, it seems that the CJEU will have to stretch the boundaries of the Directive once again in order to accommodate the tension between fundamental rights in the Afghanistan Papiere case within the closed system of exceptions and 
limitations. This could be done, for example, by interpreting the conditions for invoking the exceptions for quotation and press in such a way that these exceptions can also be invoked with regard to non-published works, thereby not having to break open the closed system. However, the CJEU's ad hoc approach of broadly interpreting the limitations and exceptions in cases where unforeseen or unanticipated clashes occur between copyright and other fundamental rights seems detrimental to the legal certainty and level of protection the Directive seeks to provide for copyright holders. Therefore, this approach might eventually undermine the objective of the EU's harmonisation efforts, namely to promote investments in creativity and innovations in order to increase the global competitiveness of European industry while protecting the fundamental rights and interests of others. Moreover, this approach would mean the potential for clashes between the CJEU and ECtHR continues to persist. Both copyright and other fundamental rights play a vital role in today's information society and hence deserve to be protected in accordance with their own merits. ${ }^{79}$ Hopefully, the preliminary questions of the German Federal Supreme Court will serve as a basis for the CJEU to clarify the exact role that fundamental rights play in the Copyright Framework of the European Union, and to carefully consider the sustainability of its long-held approach of sticking to the exhaustive list of exceptions and limitations.

Acknowledgements The authors want to thank Stefan Kulk, Professor Paul Geerts and Roeland de Bruin for their time and their helpful comments during the writing of the article. The authors would also like to thank Waleed Mahmoud for his contribution to the research paper that formed the basis for this article.

Open Access This article is distributed under the terms of the Creative Commons Attribution 4.0 International License (http://creativecommons.org/licenses/by/4.0/), which permits unrestricted use, distribution, and reproduction in any medium, provided you give appropriate credit to the original author(s) and the source, provide a link to the Creative Commons license, and indicate if changes were made.

\section{References}

de Búrca G (2013) After the EU Charter of Fundamental Rights: the Court of Justice as a human rights adjudicator? Maastricht J Eur Comparat Law 20:168-184

de Cock Buning M (2014) Ashby Donald; commercial speech en uitingsvrijheid in het auteursecht. IER 2014/36: 242-245

Douglas-Scott S (2011) The European Union and Human Rights after the Treaty of Lisbon. Hum Rights Law Rev 11:645-682

Dreier T (2010) Limitations: the centerpiece of copyright in distress. J Intellect Prop Inf Technol Electron Commerce Law 1:50-54

\footnotetext{
79 Although the proposed Directive on copyright in the Digital Single Market adds some exceptions and limitations, particularly with regard to new techniques such as data mining, an open norm is not included in the proposal. See also for a broader interpretation of the three-step test Geiger and Schönherr (2014), p. 443. An example of an open norm in order to accommodate societal interests can be found in the fair use approach of the United States or - closer to home - in the approach under the 2015 Trade Mark Directive (Directive (EU) 2015/2436), providing in Recital 27 that "[t]he exclusive rights conferred by a trade mark should not entitle the proprietor to prohibit the use of signs or indications by third parties which are used fairly and thus in accordance with honest practices in industrial and commercial matters".
} 
Geiger C (2009) The future of copyright in Europe: striking a fair balance (Report for the Committee on Culture, Science and Education-Parliamentary Assembly, Council of Europe 2009)

Geiger C, Izyumenko E (2014) Copyright on the human rights' trial: redefining the boundaries of exclusivity through freedom of expression. IIC 45:316-342

Geiger C, Schönherr F (2014) The Information Society Directive. In: Stamatoudi I, Torremans P (eds) EU Copyright Law. Edward Elgar Publishing, Cheltenham

Gielen C et al (2017) Kort Begrip van het Intellectuele Eigendomsrecht. Wolters Kluwer, Deventer

Griffiths J (2011) Infopaq, BSA and the "Europeanisation" of United Kingdom copyright law. Media Arts Law Rev 16:59-72

Griffiths J (2014) The role of the Court of Justice in the development of the European Union copyright law. In: Stamatoudi I, Torremans P (eds) EU Copyright Law. Edward Elgar Publishing, Cheltenham

Grosheide FW (2010) Intellectual property and human rights. Edward Elgar Publishing, Cheltenham

Groussot X (2008) Music production in Spain (Promusicae) vs. Telefonica de Espana SAU-Rock the KaZaA: another clash of fundamental rights. Common Mark Law Rev 6:1745-1766

Harpaz G (2009) The European Court of Justice and its relations with the European Court of Human Rights: the quest for enhanced reliance, coherence and legitimacy. Common Mark Law Rev $1: 105-141$

Hartkamp AS (2016) European law and national private law, 2nd edn. Intersentia, Cambridge

Helfer L (2003) Human rights and intellectual property: conflict or coexistence? Minnesota J Law Sci Technol 1:47-61

Hugenholtz B (2013) Is harmonization a good thing? The case of the copyright acquis. In: Pila J, Ohly A (eds) The Europeanization of intellectual property law: towards a European legal methodology. Oxford University Press, Oxford

Izyumenko E (2016) The freedom of expression contours of copyright in the digital era: a European perspective. J World Intellect Prop 19:115-130

Jans JH et al (2015) Europeanisation of public law. Europa Law Publishing, Amsterdam

Jütte BJ (2016) The beginning of a (happy?) relationship: copyright and freedom of expression in Europe. Eur Intellect Prop Rev 38:11-22

Klimas T, Vaiciukaite J (2008) The law of recitals in European Community legislation. ILSA J Int Comp Law 1:61-93

Kokott J, Sobotta C (2015) Protection of fundamental rights in the European Union: on the relationship between EU fundamental rights, the European convention and national standards of protection. Yearbook European Law 34:60-73

Kosta V (2015) Fundamental rights in EU internal market legislation. Hart Publishing, Oxford

Krommendijk J (2015) The use of ECTHR case law by the CJEU after Lisbon: the view of the Luxembourg insiders. Maastricht J Compa Eur Law 22:812-835

Mazziotti G (2013) Copyright in the EU digital single market. https:/www.ceps.eu/system/files/ Copyright\%20in\%20the\%20EU\%20Digital\%20Single\%20Market\%20FINAL\%20e-version.pdf. Accessed 20 May 2018

Mjoll Arnardottir O, Buyse A (2016) Shifting centers of gravity in human rights protection. Routledge, Abingdon-on-Thames

Morana-Foadi S, Andreadakis A (2011) The convergence of the European legal system in the treatment of third country nationals in Europe: the ECJ and ECtHR jurisprudence. Eur J Int Law 22:1071-1088

Renda A et al (2015) The implementation, application and effects of the EU Directive on Copyright in the information society. https://www.ceps.eu/system/files/SR120_0.pdf. Accessed 20 May 2018

Torremans PLC (2014) Ashby Donald and others v. France, application 36769/08, EctHr, 5th section, judgment of 10 January 2013. Queen Mary J Intellect Prop 4:95-99

van Eechoud M et al (2009) Harmonizing European copyright law. The challenges of better lawmaking. Wolters Kluwer, Deventer

Visser D (2012) Kroniek van de Intellectuele Eigendom. Nederlands Juristenblad 884:1041-1049

Voorhoof D, Høedt-Rasmussen I (2013) Copyright vs. freedom of expression: the case Ashby Donald and others v. France. https://biblio.ugent.be/publication/3156078/file/3156086. Accessed 10 April 2018

Walter M (2001) Freie Nutzungen. In: Walter M (ed) Europäisches Urheberrecht. Springer, Vienna

Xalabarder R (2016) The role of the CJEU in harmonizing EU copyright law. Int Rev Intellect Prop Compet Law 6:635-639 